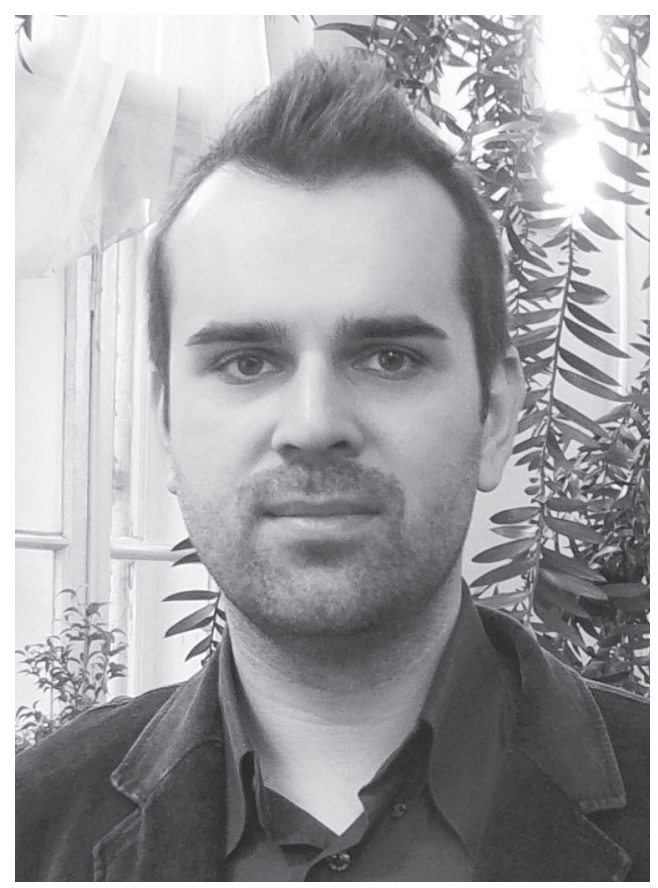

UDC: $35.071: 124.2$

Dovgan'Aleksej Valentinovich, Candidate of philological sciences, Corresponding Member of the International Academy of Education, Deputy Director, Scientific Library of the National Academy of Managerial Staff of Culture and Arts, 02000, Kyiv, Str.Lavrska, 9, tel.: +38(050) 7202003 , e-mail:dovgan396@gmail.com

ORCID: 0000-0002-6728-818X

Довгань Олексій Валентинович, кандидат філологічних наук, илен-кореспондент Міжнародної академії освіти $i$ науки, заступник директора, Наукова бібліотека Наиіональної академії керівних кадрів культури й мистеитвв, 02000, м. Київ, вул.Лаврська, 9, тел.: +38 (050) 720 20 03,e-mail:dovgan396@gmail.com

ORCID: 0000-0002-6728-818X

Довгань Алексей Валентинович, кандидат филологических наук, илен-корреспондент Международной академии образования и науки, заместитель директора, Научная библиотека Национальной академии руководящих кадров культуры и искусств, 02000, г. Киев, ул. Лаврская, 9, тел.: +38 (050) 72020 03, e-таil: dovgan396@ gmail.com

ORCID: 0000-0002-6728-818X

\title{
PUBLIC ADMINISTRATION FROM THE STANDPOINT OF DETERMINISTIC SOCIAL SENSE (ARCHETYPAL APPROACH)
}

Abstract. The features and the role of deterministic social sense in the context of the archetypical approach are considered in the article; the specifics of the existence of the above-mentioned phenomenon in relation to public administration are presented. The nature, principles of the functioning of archetypes as a direct, pragmatic decision-making factor of the personality are represented. It is argued that archetypes are significantly different from those historically established or transformed by human characters, whose senses are not mentally inherited, but transmitted from generation to generation. The emphasis is placed on the relevance of the archetypal approach for research in the management sector in general and deterministic social sense - in particular. The author emphasizes that the archetype is a direct pragmatic factor in personal decision-making, acting as a created internal complication that ensures the course of certain socially deter- 
mined processes in the human brain. Attention is focused on the continuity of the concepts of "sense" and "culture": from the moment of alienation of a person from the surrounding natural world, all thoughts, created things, found and used means and methods of actions are given meanings. Thus, the decision, that is, the choice, appears to be the natural basis for an individual's being in ontological reality, acting as a necessary precondition for structuring his administrative, legal and so on needs in modern society. Further investigation of the archetypal approach to the study of the phenomenon of deterministic social sense is seen in the study of the features of citizens' reflection on the images and symbols created by the government in order to achieve some behavioral manifestations in the latter, allowing more deeply and clearly understand the needs of the people, and also to update the relevant role of public administration in his life. At the same time, from the standpoint of social, psychological, culturological pragmatics etc., the archetype is the primary form of sense stratified according to the types described by Jung. This differentiation of this phenomenon is natural, due to its universalism, which allows us to speak about the degree of social adaptability of the latter.

Keywords: sense, social sense, deterministic sense, public administration, archetype, archetypal approach.

\section{ПУБЛІЧНЕ УПРАВЛІННЯ 3 ПОЗИЦІЙ ДЕТЕРМІНОВАНОГО СОЦІАЛЬНОГО СМИСЛУ (АРХЕТИПНИЙ ПІДХІД)}

Анотація. Розглянуто особливості й роль детермінованого соціального смислу в контексті архетипного підходу; презентовано специфіку побутування зазначеного феномену відносно публічного управління. Репрезентовано природу й принципи функціонування архетипів як безпосереднього прагматичного чинника ухвалення рішень особистістю. Стверджується, що архетипи суттєво відрізняються від історично усталених або перероблених людиною символів, значення яких не є психічно успадкованими, тим, що вони передаються з покоління в покоління. Акцентується увага на актуальності архетипного підходу для досліджень управлінської сфери в цілому й детермінованого соціального смислу зокрема. Автор наголошує, що архетип постає безпосереднім прагматичним чинником ухвалення рішень особистістю, виступаючи у ролі витвореного внутрішнього ускладнення, що забезпечує перебіг певних соціально-детермінованих процесів у мозку людини. Акцентується увага на нерозривності понять “смисл” і “культура”: з моменту відчуження людини від довколишнього природного світу всі створені нею думки, створені речі, знайдені й використовувані засоби та способи дій наділяються смислами. Таким чином, рішення, тобто вибір, постає як природна основа побутування індивідуума в онтологічній реальності, виступаючи необхідною передумовою структурування його адміністративних, правових тощо потреб у сучасному суспільстві. Подальше дослідження архетипного підходу до вивчення феномену детермінованого соціального смислу вбачається у дослідженні особливостей рефлексії громадян на витворювані урядом образи й символи з метою досягнення певних поведінкових виявів в останніх, що 
дозволить більш глибоко й чітко розуміти потреби народу, а також актуалізувати релевантну роль публічного управління в його житті. При цьому з позицій мовної, соціальної, психологічної, культурологічної тощо прагматики архетип виступає первинною формою смислу, стратифікованою за описаними Юнгом типами. Така диференціація цього феномену є природною, внаслідок його універсалізму, що дозволяє говорити про ступінь соціальної адаптивності останнього.

Ключові слова: смисл, соціальний смисл, детермінований смисл, публічне управління, архетип, архетипний підхід.

\section{ПУБЛИЧНОЕ УПРАВЛЕНИЕ С ПОЗИЦИЙ ДЕТЕРМИНИРОВАННОГО СОЦИАЛЬНОГО СМЫСЛА (АРХЕТИПИЧЕСКИЙ ПОДХОД)}

Аннотация. Рассмотрены особенности и роль детерминированного социального смысла в контексте архетипического подхода; представлена специфика бытований очерченного феномена относительно публичного управления. Представлены природа и принципы функционирования архетипов как непосредственной прагматической составляющей принятия решений личностью. Утверждается, что архетипы существенно отличаются от исторически сложившихся либо переработанных человеком символов, значение которых не является психически наследованным, тем, что они передаются из поколения в поколение. Акцентируется внимание на актуальности архетипического подхода для исследований управленческой сферы в целом и детерминированного социального смысла в частности. Автор подчеркивает, что архетип непосредственным прагматическим фактором принятия решений личностью, выступая в роли созданного внутреннего осложнения, обеспечивающего ход определенных социально-детерминированных процессов в мозгу человека. Акцентируется внимание на неразрывности понятий “смысл” и “культура”: с момента отчуждения человека от окружающего естественного мира все созданные им мысли, созданные вещи, найденные и используемые средства и способы действий наделяются смыслами. Таким образом, решение, то есть выбор, представляется естественной основой бытования индивидуума в онтологической реальности, выступая необходимым предусловием структурирования его административных, правовых и так далее потребностей в современном обществе. Дальнейшее исследование архетипического подхода к изучению феномена детерминированного социального смысла усматривается в исследовании особенностей рефлексии граждан на создаваемые правительством образы и символы с целью достижения неких поведенческих проявлений у последних, позволяющих более глубоко и четко понять потребности народа, а также актуализировать релевантную роль публичного управления в его жизни. При этом с позиций социальной, психологической, культурологической прагматики и так далее архетип выступает первичной формой смысла, стратифицированной по описанными Юнгом типами. Такая дифференциация этого феномена является естественной, вследствие ее 
универсализма, позволяющего говорить о степени социальной адаптивности последнего.

Ключевые слова: смысл, социальный смысл, детерминированный смысл, публичное управление, архетипический подход.

Formulation of the problem. The existence of an individual in an ontological reality is inseparable from the features of his physicality, self-identification, communication, etc. The latter produces the conclusion that in the basis of the described process located the archetype, which, according to K. Jung, is deeply unconscious, in which hidden universal, original images [9, p. 80]. In turn, this gives us the opportunity to postulate its great socio-communicative significance: after all, any socially predetermined processes carry in their structure a certain archetypal significance that is relevant to a socially deterministic sense.

Analysis of recent publications on the issues and identification of previously unsettled parts of the general problem. An outline of the problem has been expressed in a number of scientific studies of such authors: M. Alexandrova, E. Afonin, V. Bortnikov, V. Budanov, M. Weber, O. Donchenko, D. Iston, P. Lazarsfeld, G. Lassuel, O. Meleshkina, C. Merriam, D. Olshansky, A. Radchenko, S. Rokcan, O. Shetopal and others.

Wording of purpose (purpose of the article). The purpose of this article is to consider the peculiarities and the role of deterministic social sense in the context of an archetypal approach. The subject is the specificity of the existence of the above-mentioned phenomenon in relation to public administration.
Presentation of the main research material with full justification of the received scientific results. From the point of view of linguistic, social, psychological, cultural, etc., pragmatics, the archetype acts as the primary form of sense, which is stratified according to the types described by Jung. At the same time, such a differentiation of this phenomenon is natural, due to its universalism, which allows us to speak about the degree of social adaptability of the latter. So, the architecture, customary for us in the form of immovable structures, was created, in fact, solely as ideas embodied in a visual form [2]. The latter is explained by the fact that the absolute majority of its forms is in a projective (drawing) form, while the materialized is an extremely small percentage.

Thus, sense can be positioned as a discourse in relation to archetype, since it appears as a material from which later form will be formed (in fact, the archetype itself, which is positioned not merely as a form but as such, but a kind of limit on the atomization of a certain area of semantic tissue/substance from another, which acquires autonomy relative to the environment). Such a broad interpretation of the outlined concept seems productive due to the fact that it allows a more detailed consideration of its psychosocial connections. In its turn, the aforesaid produces an understanding of the outlined limits of sense as a pre-written, pre-linguistic conven- 
tion [5]. In this case, the positioning of value-semantic archetypal forms of communicative space, which unfolds the implementation of psychosocial characteristics.

There is a definition of the archetype by which he is positioned as a deep form of the collective unconscious, the form without sense, which, manifested in the individual consciousness, acquires a specifically figurative character that can be explored and comprehended [1]. However, we can not agree with this definition, since the archetype is, in our understanding, a form with sense, but the very nature of this content is determined by the social sense through the actualization of the anthropological determinants, that is, the categorization of sense, its particular design, etc., is a process of social determinism. In addition, the archetype can, to a certain extent, be positioned as a preform, since its sense has a great degree of anthropocentrism, but it is not fully incorporated into culture as such.

At the same time, the latter is a complex, multidimensional phenomenon that can be viewed from different positions, formulating various systems of its description, and each time receiving new characteristics of the latter. In modern philosophy of culture, there are many points of view on it, a number of definitions of the essential foundations of the latter. So, various scientific schools interpret it differently, concentrating attention on one aspect or another. Accordingly, there is not one, but many theories of culture, many research approaches, methods for its study [7, p. 3].

Thus, we consider the expanded approach to the notion of culture from the standpoint of public administration as justifiable: as a spiritual achievement of mankind, represented in a number of forms of the ideal (idea) and physical (things) of nature. According to this interpretation, the concept of culture should be understood as archetypically structured segments of reality, adapted through the categorization of the human brain. Thus, we are talking already about trans-individual, but essentially, intrapsychic phenomena, fixed in the brain, similar to the instincts of animals, which allows, in turn, to postulate the presence of the phenomenon of synchronicity [4] (ie, the simultaneous deployment of a particular mental state with one or more external events that look like semantic analogues of the instant subjective state).

As for public administration, it is expedient to talk directly about the peculiarities of the deterministic social sense, one of whose goals is the phenomenon of self. By its nature, this phenomenon should be positioned as a psychological total, which can be equated with the ancient Indian notion of "ataman" or the ancient Chinese "dao". In addition, in this light, the specificity of the Japanese concept of "m" as a destructive emptiness, contrasted with the "fullness" of personality, is interesting in this light. Consequently, self - a concept that expresses the human essence, since all the origins of spiritual life come from this point of non-return: it cumulates all the highest and last goals [3, p. 48].

That is why the self for the public administration appears to be the milestone of the social existence of the individual, whose problem is connected with the problem of choice for the defined sphere as a differentiating feature 
of its stratification as a social individual. Thus, the very existence of a person can be positioned as the sum of all its elections made during a lifetime: in this way, the person acts as a consumer of goods, services, etc., created to secure their socially determined aspirations (V. Peliewin's “Generation P”, F. Beigbeder's "99 francs" and other artistic works, which refer to the psychological, economic and social basis of such a process).

Naturally, with the fact that the choice is the result of a solution, the essence of its adoption can be characterized as an internal, relatively stable basis that defines the sense, role and place of the latter in the functioning and development of the institution (organization, enterprise, etc.). Therefore, the essence of decision-making, as a rule, is manifested through a variety of external connections and actions that characterize one of the parties [6, p. 6].

Concerning the adoption of one or another solution, archetypes should be perceived as images or thought schemes that are filled with the implied sense that allow a person to organize his life experience and perception of the external world, which is manifested through forms of behavior [1]. At the same time, their interpretation does not require mental effort, because they are perceived at the unconscious level and have a single sense for all mankind $[8$, p. 124].

Thus, we postulate the subjectivity of the above processes, which can be positioned as a natural basis for its deployment, limited by professional (in the case of being in the business sphere) and personal (moral, psychological, etc.) determinants. The latter are con- sonant with a view of modern society as representing information as a basic, core component that is relevant to the managerial field.

Conclusions and perspectives of further research. Consequently, the archetype appears as a direct pragmatic factor in decision-making by the individual, acting as a created internal difficulty, which ensures the course of certain social deterministic processes in the human brain. At the same time, archetypes differ significantly from historically established or transformed by human characters whose values are not mentally inherited, but transmitted from generation to generation [8, p. 124]. The latter allows us to conclude that the relevance of the archetypal approach to research in the management sphere as a whole and deterministic social sense - in particular.

Also, we emphasize the indissolubility of the concepts of "sense" and "culture": since the alienation of man from the surrounding natural world, all created by her thoughts, created things, found and used means and methods of action endowed with sens [8, p. 122]. Thus, the solution, that is, the choice, appears as the natural basis of the individual's existence in an ontological reality, acting as a prerequisite for the structuring of his administrative, legal, etc. needs in modern society.

A further study of the archetypical approach to the study of the phenomenon of deterministic social sense is seen in the study of the peculiarities of the reflection of citizens on the images and symbols created by the government in order to achieve certain behavioral manifestations in the latter, which will allow more deeply and clearly under- 
stand the needs of the people, as well as actualize the relevant role of public administration in its life.

\section{REFERENCES}

1. Jung K. G. (2010), Psychology of the unconscious, 2nd ed., Kogito Center, Moscow, Russian Federation.

2. Bass V. (2018) "Paper architecture", PostNauka [Online], available at: https://postnauka.ru/faq/68819 (Accessed 4 April 2018).

3. Dudakov-Kashuro K. (2016) "Dadaism”, PostNauka [Online], available at: https://postnauka.ru/faq/70906 (Accessed 4 April 2018).

4. "Archetype", Concepts and categories: auxiliary project of the portal "Chronos" [Online], available at: http://ponjatija.ru/taxonomy/ term/1593 (Accessed 4 April 2018).

5. Kolchanova E. A. (2006) "Archetype" as a category of the philosophy of culture": abstract of Art. Candidate of Philosophical Sciences Dissertation, Public Admnistration, Tyumen State University, Tyumen, Russian Federation.

6. Grof S. (2004) "Archetypes, mythical imagination and modern society: a new charm for the world", Stanislav Grof: personal site [Online], available at: http://stanislavgrof.ru/articles/ arhetipy-mificheskoe-voobrazheniei-sovremennoe-obshhestvo-novoeocharovanie-dlya-mira.html (Accessed 4 April 2018).

7. Vertel A. (2013), "Archetype of the Self: Holism in the Philosophy of K. G. Jung”, Naukovy Visnik Chernivtsi University: Zbirnyk nauk. etc., Vyp. 646/647, p. 45-51.

8. Kolpakov V. M. (2004) Theory and practice of making managerial decisions: Textbook. Allowance, $2^{\text {nd }}$ ed., recycled and additional, SAMP, Kyiv, Ukraine.
9. Koshetarova L. N. (2010), "Archetype and the symbol as the main forms of expression of cultural sense by advertising", Knowledge. Understanding. Skill, № 4, p. 122-126.

\section{СПИСОК ВИКОРИСТАНИХ ДЖЕРЕЛ}

1. Юнг К. Г. Психология бессознательного / К. Г. Юнг; пер. с англ. 2-е изд. - Москва : Когито-Центр, 2010. -352 c.

2. Басс B. Бумажная архитектура [Электронный ресурс] / В. Басс // ПостНаука. - Режим доступа: https://postnauka.ru/faq/68819

3. Дудаков-Кашуро К. Дадаизм [Электронный ресурс] / К. Дудако-Кашуро // ПостНаука. - Режим доступа: https://postnauka.ru/faq/70906

4. Архетип [Электронный ресурс] // Понятия и категории : вспомогательный проект портала “Хронос”. Режим доступа: http://ponjatija.ru/ taxonomy/term/1593

5. Колчанова E. А. “Архетип” как категория философия культуры : дис. ... канд. филос. наук : спец. 24.00.01 / Е. А. Колчанова; Тюменский гос. ун-т. - Тюмень, 2006. - 160 с.

6. Гроф $C$. Архетипы, мифическое воображение и современное общество: новое очарование для мира [Электронный ресурс] / С. Гроф // Станислав Гроф: персональный сайт. Режим доступа: http://stanislavgrof. $\mathrm{ru} /$ articles/arhetipy-mificheskoe-voobrazhenie-i-sovremennoe-obshhestvonovoe-ocharovanie-dlya-mira.html

7. Вертель А. Архетип самости : холизм в философии К. Г. Юнга / А. Вертель // Наук. вісн. Чернівецького ун-ту: зб. наук. пр. - Вип. 646/647. - C. 45-51.

8. Колпаков B. М. Теория и практика принятия управленческих решений: учеб. пособие / В. М. Колпаков. - 
2-е изд., перераб. и доп. - Киев : МАУП, 2004. - 504 c.

9. Кошетарова Л. Н. Архетип и символ как основные формы выраже- ния культурных смыслов реклами / Л. Н. Кошетарова // Знание. Понимание. Умение. - 2010. - № 4. C. 122-126. 